\title{
Physical and Chemical Quality Profile of Lamb Meat Which Was Swamp Buffalo's Rumen Liquid Based Fodder-Fed
}

\author{
Tintin Rostini ${ }^{1}$, Danang Biyatmoko ${ }^{2}$, Irwan Zakir ${ }^{1} \&$ Arief Hidayatullah ${ }^{1}$ \\ ${ }^{1}$ Department of Animal Husbandry, Faculty of Agriculture, Islamic University of Kalimantan, Indonesia \\ ${ }^{2}$ Department of Animal Husbandry, Faculty of Agriculture, Universitas Lambung Mangkurat, Indonesia \\ Correspondence: Tintin Rostini, Department of Animal Husbandry, Faculty of Agriculture, Islamic University of \\ Kalimantan, Indonesia. E-mail: tintin_rostini@yahoo.com
}

\author{
Received: October 9, 2018 \\ Accepted: February 1, 2019 \\ Online Published: April 15, 2019 \\ doi:10.5539/jas.v11n5p547 \\ URL: https://doi.org/10.5539/jas.v11n5p547
}

\begin{abstract}
This study aims to know the effect of swamp buffalo's rumen liquid based fodder toward physical and chemical quality of lamb meat. This study used 12 male Kacang goats at age of 10-12 months with weight around $12 \pm 1.2$ $\mathrm{kg}$. Method used in this study was Completely Randomized Design with 4 treatments repeated for 3 times until it reached 12 units of trials. The treatments consist of: (PS), regular fodder given by breeder (PFCK1) 25\% rumen liquid based fodder $+75 \%$ PS. (PFCK2), 50\% rumen liquid based fodder $+50 \%$ PS. (PFCK3) $75 \%$ rumen liquid based fodder $+25 \%$ PS. Data was statistically analyzed by using variance analysis. Difference between treatments was tested by using Duncan's New Multiple Range Test. Study results showed that the usage of rumen liquid based fodder of $75 \%$ increased protein and lamb fat content $(\mathrm{P}<0.05)$, the lamb meat was physically more tender $(\mathrm{P}<0.05)$. The conclusion is swamp buffalo's rumen liquid could be used to enhance lamb meat quality.
\end{abstract}

Keywords: rumen liquid, lamb, physical, quality

\section{Introduction}

Nowadays, meat consumption in Indonesia has increased along with the population growth and development, and the societies' awareness level of nutrients consumption coming from meat. Lamb is one of the meats widely loved by Indonesians (Soedjana, 2011).

Meat quality can be seen from lamb's physical and chemical quality (Rostini dan Zakir, 2012). Meat physical quality is affected by $\mathrm{pH}$ factor and tenderness, while meat chemical quality is determined by before and after butchery factor. Before butchery factors which affect meat quality are genetic, species, order, cattle type, gender, age, fodder and additives (hormone, antibiotics, and mineral), and also stress level. After butchery factors that affect meat quality are aging method, concoction method, intramuscular fat (marbling), meat acidity level ( $\mathrm{pH}$ ), additional elements (including meat tenderizing enzyme), conservation and preservation method, meat muscle type, and muscle location (Mirdhayati et al., 2014). Meat chemical quality for every order of goat is not the same; the meat composition is varied and affected by cattle type, age, fodder given when the cattle was alive, and cattle order. The average chemical composition of meat is as follows: protein is varied between $16-22 \%$, fat $1.5-13 \%$, non protein nitrogen compound $1.5 \%$, inorganic compound $1 \%$, carbohydrate $0.5 \%$, and water between $65-80 \%$ (Soeparno, 1998).

Fodder given to goats highly affects the meat quality. The commonly used fodders are mostly forage and legumes, and also plantation and agricultural waste. Fodder with enough nutrients content for fulfilling cattle's needs will result on good productivity; the fodder quality is very important for meat contribution (Cahyani et al., 2012). The study result of Rostini et al. (2014) showed that fodder made from plantation and agricultural waste has limitation factor if it was directly given to cattle and it was less palatable for the cattle. In this case, technology was needed in the waste processing so that it could be palatable for cattle.

This study aims to know the effect of swamp buffalo's rumen liquid based fodder toward lamb meat physical and chemical quality. 


\section{Methodology}

This study used 12 male goats in the growth period with the average weight of $12 \pm 1.2 \mathrm{~kg}$ (variance coefficient $15.20 \%$ ). Individual goat cage's size was $1 \mathrm{~m} \times 1.5 \mathrm{~m}$ as much as 12 cages, whilst the used tools were fodder bowl (basin), bucket of drinking water, and name label. Study treatments consist of: (PS), regular fodder given by breeder (PFCK1) $25 \%$ rumen liquid based fodder $+75 \%$ PS. (PFCK2), $50 \%$ rumen liquid based fodder + $50 \%$ PS. (PFCK3) $75 \%$ rumen liquid based fodder $+25 \%$ PS. The study was done in Faperta Uniska cage, Food Technology Laboratory in IPB, and Post-Harvest Laboratory in Cimanggu Bogor. This study used fermented fodder based on buffalo's rumen liquid. Fodder constituent nutrient content is provided in Table 1.

Table 1. Chemical composition of field grass, legumes, and complete forage wafers

\begin{tabular}{llll}
\hline Fodder nutrients & Field grass & Legume & Buffalo's rumen liquid fermented fodder* \\
\hline Dry ingredients & 20.12 & 27.86 & 84.12 \\
Crude protein & 9.21 & 18.43 & 14.21 \\
Crude fiber & 25.12 & 23.2 & 22.56 \\
Crude fat & 2.85 & 0.12 & 3.12 \\
BetN & 54.86 & 42.65 & 45.21 \\
TDN & 51.86 & 52.72 & 58.42 \\
NDF & 63 & 58.93 & 42.58 \\
ADF & 45.25 & 38.28 & 35.23 \\
Ca & 0.54 & 0.32 & 1.2 \\
P & 0.72 & 0.64 & 0.86 \\
\hline
\end{tabular}

Note. Fermented fodder $*=50 \%$ legume $+25 \%$ forage $+15 \%$ concentrate $+10 \%$ rumen liquid analyzed in integrated laboratory IPB.

\subsection{Fermented Fodder Making (PFCK)}

The fermentation process was done with anaerobe method for 7 days by using rumen liquid as the fermenter. Before the fermentation, forage was cut into pieces at $2-5 \mathrm{~cm}$ and wind dried for 5 days until it reached $60 \%$, then fodder ingredients and forage was mixed. Fermentation ingredient compositions were: forage + bran $(1.5 \%$ from ingredients weight $)+$ urea $(0.5 \%$ from ingredients $)+$ molasses + rumen liquid $(10 \%$ from ingredients weight), all the ingredients was mixed and then fermented.

\subsection{Research Design}

Research design used in this study was Completely Randomized Design with 4 treatments repeated for 3 times until it reached 12 unit trials. Fodder was given corresponding to the treatments; it was given twice a day at 08.00 in the morning and at 15.00 in the afternoon.

\subsection{Observed Variable}

Measured variables were physical and chemical characteristics of meat (colour, smell, taste, juiciness and tenderness), and chemical quality ( $\mathrm{pH}$, water holding capacity, fat, protein, and cholesterol). Data was analyzed by variance analysis (ANOVA) and if it was real different then advanced test was needed (Steel dan Torrie, 1993).

\section{Result and Discussion}

\subsection{Goat Carcass Quality}

The quality of carcass in this study showed that fodder treatments really affected the carcass percentage $(\mathrm{P}<0.05)$ on PFCK 3 treatment by giving rumen liquid waste based fermented fodder. 
Table 2. Carcass and non-carcass Kacang goat's quality which was given swamp buffalo's rumen liquid based fodder

\begin{tabular}{lllll}
\hline \multirow{2}{*}{ Parameter } & \multicolumn{3}{c}{ Treatments } \\
\cline { 2 - 5 } & PS & PFCK $(25 \%)$ & PFCK (50\%) & PFCK (75\%) \\
\hline Carcass (\%) & $42.4^{\mathrm{a}} \pm 2.4$ & $42.8^{\mathrm{a}} \pm 3.8$ & $44.3^{\mathrm{b}} \pm 3.8$ & $47.6^{\mathrm{b}} \pm 2.8$ \\
Head (\%) & $5.6^{\mathrm{a}} \pm 0.3$ & $5.8^{\mathrm{a}} \pm 0.3$ & $5.9^{\mathrm{a}} \pm 0.3$ & $6.19^{\mathrm{b}} \pm 0.3$ \\
Skin (\%) & $9.1^{\mathrm{a}} \pm 0.3$ & $6.5^{\mathrm{b}} \pm 0.4$ & $6.1^{\mathrm{b}} \pm 0.4$ & $6.2^{\mathrm{b}} \pm 0.9$ \\
Gross digestive tract (\%) & $21.9 \pm 0.3$ & $20.9 \pm 1.2$ & $20.2 \pm 1.2$ & $20.7 \pm 0.7$ \\
Blood (\%) & $1.9 \pm 0.4$ & $2.9 \pm 0.0$ & $2.1 \pm 0.1$ & $2.1 \pm 0.1$ \\
Leg (\%) & $2.2 \pm 0.3$ & $1.9 \pm 0.7$ & $1.9 \pm 0.7$ & $2.1 \pm 0.3$ \\
\hline
\end{tabular}

Note. (PS), regular fodder given by breeder (PFCK1) 25\% rumen liquid based fodder $+75 \%$ PS. (PFCK2), $50 \%$ rumen liquid based fodder $+50 \%$ PS. (PFCK3) $75 \%$ rumen liquid based fodder $+25 \%$ PS.

The percentage of carcass showed that rumen liquid based fodder could increase the percentage of goats' carcass, where on PFCK 3 treatment produced the highest carcass percentage of $47.8 \%$, followed by PFCK2 and PFCK1 treatment; the lowest was on PS treatment with the percentage of $42.4 \%$. The percentage of male Kacang goats' carcass gained in this study was higher than the results on Muhtadi's (2004) study which presented that the percentage of carcass of two-year-old goat was $42.68 \%$ (Sunarlim \& Usmiati, 2006). It showed that swamp buffalo's rumen liquid based fermented fodder could obtain higher percentage of goats' carcass.

\subsection{Goats' Carcass Physical Quality}

Physical quality of Kacang goats' carcass in this study showed unreal difference $(\mathrm{P}<0.05)$ between treatments, even though there were differences of smell, colour, and taste; however, by increasing the use of rumen liquid based fermented fodder, the score value of goats' carcass physical quality was also increased.

Table 3. Average score of lamb meat physical quality which was given swamp buffalo's rumen liquid based fodder

\begin{tabular}{lllll}
\hline Variable & PS & PFCK1 & PFCK2 & PFCK3 \\
\hline Colour & $2.56 \pm 0.7$ & $2.56 \pm 0.7$ & 2.6710 .1 & $2.67 \pm 0.9$ \\
Smell & $2.43 \pm 0.6$ & $2.56 \pm 0.1$ & $2.62 \pm 0.3$ & $2.75 \pm 0.4$ \\
Taste & $2.54 \pm 0.7$ & $2.62 \pm 0.1$ & $2.67 \pm 0.1$ & $2.72 \pm 0.5$ \\
Juiciness (marbling) & $2.72 \pm 0.4$ & $2.81 \pm 0.2$ & $2.84 \pm 0.4$ & $2.98 \pm 0.3$ \\
Tenderness $\left(\mathrm{kg} / \mathrm{cm}^{3}\right)$ & $2.53 \pm 0.2$ & $2.62 \pm 0.1$ & $2.71 \pm 0.2$ & $2.76 \pm 0.2$ \\
\hline
\end{tabular}

Note. (PS), regular fodder given by breeder (PFCK1) 25\% rumen liquid based fodder $+75 \%$ PS. (PFCK2), $50 \%$ rumen liquid based fodder $+50 \%$ PS. (PFCK3) $75 \%$ rumen liquid based fodder $+25 \%$ PS.

Juiciness (marbling) is fat located between muscle fibers (intramuscular). Fat serves as muscle wrapping and maintains meat wholeness while being heated. Marbling affects the taste of meat. The study result showed that the usage level of rumen liquid based fermented fodder had no real effect $(\mathrm{P}<0.05)$ between treatments, but it affected meat juiciness level. It might due to the mixture of swamp buffalo's rumen liquid based fodder which produced fat on PFCK3 treatment in which it had fat content of 4,98\% that marked higher level of meat fat. It corresponded to Maruddin (2004) who stated that marbling or juiciness in meat which was high level of fat fodder-fed caused fat deposit in meat which affected tenderness, brightness, and consumer acceptance.

Meat tenderness between treatments had no significant result $(\mathrm{P}<0.05)$, it was because of similar goats' age which was 1.5 years old in average; on the other hand, the usage level of buffalo's rumen liquid based fermented fodder up until $75 \%$ showed higher tenderness of meat compared to other treatments. It was because fermented fodder had gross fiber content of $24.67 \%$ which was higher than other treatments, so that it increased the lamb meat's tenderness. This result was in accordance with Sutardi (1997) who stated that gross fiber in digestive tract could trap fat, so that the absorbed food substance in cattle's body decreased. On the other hand, Wick dan Marriot (2002) stated that tenderness was one of the important sensory appendages in meat which involved meat protein degradation mechanism. The used fodder contained relatively similar protein amount around $12.24-13.62 \%$ so it could produce relatively same tenderness. 


\subsection{Lamb Meat Chemical Contents}

Lamb meat chemical contents in this study was based on $\mathrm{pH}$, water holding capacity (WHC), fat level, protein level, and cholesterol, which can be seen on Table 4.

Table 4. Average chemical contents in lamb meat which was given buffalo's rumen liquid based fermented fodder

\begin{tabular}{lllll}
\hline Variable & PS & PFCK1 & PFCK2 & PFCK3 \\
\hline $\mathrm{pH}$ & $5.14 \pm 1.2$ & $5.22 \pm 0.7$ & $5.42 \pm 0.6$ & $5.45 \pm 0.8$ \\
Water holding capacity $(\mathrm{WHC})$ & $31.75 \pm 0.8$ & $31.96 \pm 1.1$ & $32.12 \pm 2.2$ & $32.5 \pm 3.2$. \\
Fat $(\mathrm{g} / 100 \mathrm{~g})$ & $7.12 \pm 1.2$ & $7.18 \pm 0.8$ & $7.2 \pm 1.4$ & $7.16 \pm 1.1$ \\
Protein $(\mathrm{g} / 100 \mathrm{~g})$ & $17.84 \pm 1.8$ & $18.22 \pm 1.3$ & $18.54 \pm 2.7$ & $18.32 \pm 2.6$ \\
Cholesterol $(\mathrm{ml} / \mathrm{dl})$ & $68.72 \pm 2.2$ & $77.64 \pm 3.1$ & $79.58 \pm 2.8$ & $75.84 \pm 3.8$
\end{tabular}

Note. (PS), regular fodder given by breeder (PFCK1) 25\% rumen liquid based fodder $+75 \%$ PS. (PFCK2), $50 \%$ rumen liquid based fodder $+50 \%$ PS. (PFCK3) 75 rumen liquid based fodder $+25 \%$ PS.

The average $\mathrm{pH}$ of lamb meat in this treatment was 5.14-5.45. There was no real difference $(\mathrm{P}<0.005)$ between treatments but it was still in normal limit 5.4-5.5 (Lawrie, 2003). Meat's pH level would produce an open structure meat and it was demanded by consumer. However, the result in this study was lower than the one in Budiyanto and Usmiati (2009) which produced lamb meat's pH level of 5.81. It might be because of several factors such as fodder, stress level, and environment temperature which affected meat $\mathrm{pH}$ level. It corresponded to Soeparno (2009) who stated that meat's pH level was highly affected by temperature in which it could decrease water holding capacity because of muscle protein denaturation. Young (1989) proposed that if low $\mathrm{pH}$ level caused an open structure meat so it decreased water holding capacity, and if high $\mathrm{pH}$ level caused a close structure meat so the water holding capacity was high, then lower $\mathrm{pH}$ level from isoelectric point of meat protein would produce positive charge excess which caused myofilament rejection and it would give more space for water molecules to trap water (Soeparno, 2005).

Lamb meat nutrition value which has important role is protein, protein takes big role in nutrition contents while fat percentage in large number will harm the health. The average score of lamb meat nutrition is given on Table 4.

Lamb meat nutrition value did not show real difference $(\mathrm{P}>0.05)$, but there was a slight increase in meat protein in which the meat protein was $17.84 \%$ on PS treatment, and on PFCK3 treatment was $18.54 \%$, so the fodder with complete forage wafers produced higher protein level. It showed that goats which were given buffalo's rumen liquid based fermented fodder had higher percentage of meat protein, in addition, fodder given on PFCK2 treatment had protein of $13.62 \%$ so that the fodder consumed by goats contained appropriate nutrients composition based on the goats' nutrition needs. However, the result in this study was lower compared to the result in Forrest et al. (2005) whose lamb meat protein level reached 19-20\%, while Price and Schweigert (1999) got lamb meat protein around $16-22 \%$. It was in accordance with USDA (1989) who stated that some factors affecting lamb meat nutrients value were age, genetics, origin area, and fodder which contained protein source. On the other hand, Kusuma (2000) produced a slightly lower protein content of lamb meat around $18 \%$.

The average plasma cholesterol level of lamb meat in this study was around $68.72-79.58 \mathrm{ml} / \mathrm{dl}$. The cholesterol contents had real difference $(\mathrm{P}<0.05)$ between treatments, in which PS treatment was real different from PFCK3 treatment. It might be because of the fodder contents consumed by goats in which on PFCK1 treatment, the fat level was 3\%; while on PFCK3 treatment, the fat level was $4.98 \%$, so it affected the meat cholesterol level. Moreover, the gross fiber level of fodder was higher so that fiber could bind the bile acid out of intestine better than the low fiber level did. The increase of bile acid into feces would cause the liver to synthesize new bile acid which came from cholesterol; therefore in general the cholesterol would be decreased. It was in accordance with Muchtadi et al. (1993) who proposed that cholesterol inside the body came from two sources which were from food and de novo biosynthesis. Cholesterol that came from food had important role because it was the main sterol in the body, cell surface component, and intracellular membrane.

\section{Conclusion}

The use of fermented fodder based on swamp buffalo's rumen liquid could increase the quality of lamb meat. 


\section{Acknowledgements}

Thanks are conveyed to the director of research and community service, directorate general of Higher Education (DRPM Dikti) who has funded this research in the competency grant research scheme for the 2018 budget year.

\section{References}

Budiyanto, A., \& Usmiati, S. (2009). Pengaruh Enzim Papain Terhadap Mutu Daging Kambing Selama Penyimpanan. Balai Besar Penelitian dan Pengembangan Pascapanen Pertanian, Bogor, Indonesia.

Komariah, I., Arief dan, I., \& Wiguna, Y. (2004). Kualitas fisik dan mikrobia daging sapi yang ditambah jahe (Zinger officinale roecoe) pada konsentrasi dan lama penyimpanan yang berbeda. MediaPeternakan, 28(2), 38-87.

Lawrie, R. A. (1995). Meat Science (3rd ed.). The Avi Publishing Company, Inc., Westport, Connecticut.

Maruddin, F. (2004). Kualitas daging sapi asap pada lama pengasapan dan penyimpanan. Jurnal Sains dan Teknologi, 4(2), 83-90.

Mirdhayati, I., Hermanianto, J., Wijaya, C. H., \& Sajuthi, D. (2014). Profil karkas dan karakteristik kimia daging kambing kacang (Capra aegragus hircus) jantan. JITV, 19(1), 26-34.

Muchtadi, D., Palupi dan, N. S., \& Astawan, M. (1993). Metabolisme Zat Gizi. Pustaka Sinar Harapan. Jakarta.

Price, J. F., \& Schweigert, B. S. (1971). The Science of Meat and Meat Products. San Francisco: W.H. Freeman and Company (US).

Rostini, T., \& Zakir, I. (2012). Evaluation of Complete Ration Silage on Performance and Quality of Goat Meat. Proceeding of the 2nd International Seminar on Animal Industry Jakarta.

Rostini, T., Abdullah, L., Wiryawan, K. G., \& Karti, M. H. (2014). Utilization of Swamp Forages from South Kalimantan on Local Goat Performances. Journal Media Peternakan, 37(1), 50-55. https://doi.org/10.5398/ medpet.2014.37.1.50

Soedjana, T. D. (2011). Peningkatan konsumsi daging ruminansia kecil dalam rangka diversifikasi pangan daging PSDSK 2014. Pusat Penelitian dan Pengembangan Peternakan, Bogor, Indonesia.

Soeparno. (2005). Ilmu dan Teknologi Daging. Cetakan Ketiga. Gadjah Mada University Press, Yogyakarta.

Soeparno. (2009). Ilmu dan Teknologi Daging. Cetakan Ke-4. Gadjah Mada University Press, Yogyakarta.

Steel, R. G. D., \& Torrie, J. H. (1993). Prinsip dan Prosedur Statistik (Ed. Ke-2, Sumantri B, Penerjemah). Jakarta: Gramedia Pustaka Utama.

Sunarlim, R., \& Usmiati, S. (2006). Profil Karkas Ternak Domba dan Kambing. Seminar Nasional Teknologi Peternakan dan Veteriner. Balai Besar Penelitian dan Pengembangan Pasca Panen Pertanian, Bogor, Indonesia.

Sutardi, T. (1997). Peluang dan Tantangan Pengembangan Ilmu-Ilmu Nutrisi Ternak. Orasi Ilmiah Guru Besar Tetap Ilmu Nutrisi. Fapet IPB, Bogor, Indonesia.

USDA (United state Departement of Agriculture). (2001). Nutrient data bse for standard reference, Release 14. Agricultural Research Service United States Departement of Agriculture, Maryland.

Wick, M., \& Marriot, N. G., (1999). The Relationship of the Sarcomeric Architecture to Meat Tenderness. The Ohio State University, Columbus.

\section{Copyrights}

Copyright for this article is retained by the author(s), with first publication rights granted to the journal.

This is an open-access article distributed under the terms and conditions of the Creative Commons Attribution license (http://creativecommons.org/licenses/by/4.0/). 